\title{
The Vatican, the Holocaust, AND the ArChives
}

\section{Paul O'SHEA}

Towards the end of his long pontificate, John Paul II gave several directives to the Archivists of the Archivo Secreto Vaticano (ASV)-the 'Secret Archives'. The first instruction was to finalise the cataloguing of the German files from the papacy of Pius XI (1922-1939) and have them ready for public inspection by 2003. The second instruction was similar. Once the files for Germany 1922-1939 were completed, the files for Germany and the Holy See during the war years under Pius XII were to be prepared for eventual inspection. On 15 February 2003 the ASV opened its doors to scholars who were then able to study the files from the period 1922-1939. At the beginning of 2012, it is still unclear as to when the war files will be ready, but Bishop Sergio Pagano, Prefect of the Archives since 1997, believes the files will not be available until at least 2014. He cites the sheer scale of documentation to be sorted and classified as the reason for the delay. Pagano was quick to add that there is no conspiracy involved-it is the simple fact that it takes a great deal of time for a staff of fewer than 30, of whom about 15 are trained archivists, to make their way through several million pages of documentation. ${ }^{1}$ Offers from various groups, such as the AntiDefamation League in New York, to underwrite the cost of hiring Vatican approved staff to help in the cataloguing process, have been politely and firmly declined. The Vatican also holds to the principle of releasing all the files for a papacy at one time. Since Pius XII was pope from 1939 to 1958, much of the material to be sorted is post-war and more than likely

${ }^{1}$ By comparison, the National Archives and Record Administration, the National Archive of the USA, employs some 3,000 archivists and specialists. 
outside the particular interest of Holocaust historians.

If this were the only archival source that could help explore the history of the Holocaust and the role of the Catholic Church during those years, historians and students would have justifiable claim to be suspicious and possibly be excused for indulging in conspiracy theories. It is one of the simple facts that the layers of myth surrounding the $A S V$ have obscured some important historical realities for many historians over the last half century. This essay explores one particular aspect of this problem.

\section{Archives and Archives}

It may seem trite to open with the assertion that many people, including more than a few scholars, are blithely unaware of the complexities surrounding the Vatican archives, but continued poor history-writing from several sources make it necessary. The most recent (in)famous use of the $A S V$ was undertaken by John Cornwall during the research and writing of his 1999 book Hitler's Pope. Cornwall claimed in his introduction that he had access to the $A S V$, and uncovered long-buried documents that caused him to rethink his previously positive assessment of Eugenio Pacelli. To the unobservant reader, this claim sounds impressive. But it is a matter of public record that at the time of his 'discoveries', he could only have had access to files up to 1922-long before Hitler came to the attention of the then Nuncio to Germany or to Pacelli's masters in Rome. Careful wording lends Cornwall's writing an air of professional historiography that is unjustified. ${ }^{2}$

2 See Gumpel, Peter (1999), 'Cornwell's Cheap Shot At Pius XII' in Crisis, December, 19-25. There have been literally hundreds of articles written on Cornwall and his methodology. In 2009, Cornwall admitted that his 1999 book lacked some historical rigour. 
At the same time, it is important to recognise the work of scholars who have made extensive use of the $A S V$ material since these files were made available in 2003. Using the 19221939 Germany files, books, articles and essays have been written that have helped shape and nuance our understanding of the Church's varied positions, internal debates, announcements and discussions surrounding the waxing and waning of the Weimar Republic, the National Socialist ascendency and finally, the first six years of the Third Reich. ${ }^{3}$ The sheer volume of material is enough to ensure scholars will be analysing the Catholic Church and its responses and reactions to pre-war Nazi Germany for many years. Perhaps the most significant discovery has been the layers of complex and intricate details found in the files that show the Holy See slowly feeling its way, cautiously and with major reservations, trying to find a way to live and work with the new German government; the path was, as Cardinal Pacelli remarked in 1934, 'crazy'. 4

The work undertaken by historians has been made easier through digital technology. In 2010, ASV joined with German scholars, Thomas Brechenmacher and Hubert Wolf, in projects to make available the files of the Munich-Berlin Nunciature 1917-1929, and the files of the Berlin Nunciature 1933-1939. All the material is freely available with substantial

${ }^{3}$ Among the growing number include Besier, Gerhard (2007), The Holy See and Hitler's Germany; Fattorini, Emma (2011), Hitler, Mussolini and the Vatican; Godman, Peter (2004), Hitler and the Vatican; Sale, Giovanni (2004), Hitler, la Santa Sede e gli Ebrei; Wolf, Hubert (2010), Pope and Devil; and my own work, O'Shea (2011) A Cross Too Heavy. It is also important to acknowledge the important work of Emma Fattorini's earlier work (1992), Germania e Santa Sede: Le nunziatura di Pacelli fra la Grande Guerra e la Repubblica di Weimar, which was one of the first to make use of material from the files up to 1922.

4 Paul O'Shea (2011), 153. 
contextual historical details. ${ }^{5}$ ASV provides digital copies of files upon request, making research work for students outside Rome accessible and affordable.

There are dozens of archival holdings in the Vatican State and around the city of Rome. The ASV is simply the most well known. Each of the nine Vatican departments, or to use the technical term, 'congregations', has its own archive. The Congregation for the Doctrine of the Faith (CDF), or as it was better known before 1965, the Holy Office or Inquisition, housed in the Palazzo del Sant'Uffizio, has been gradually opening its archives for scholarly research since 1996. In January 1998, all material up to 1903, the death of Pope Leo XIII, the first pope to open the $A S V$ to historians, was made readily available. Among the files were included the stories of some of the Vatican's less flattering moments-such as the trial documents of Galileo and the documents surrounding the Edgardo Mortara affair of the 1850s. ${ }^{6}$

To the unwary researcher and the equally unwary reader, the possibility of operating in ignorance of what is available remains a problem. Other archival sources that are related to the Vatican are found in places such as the Archivio di Stato di Roma on Corso del Rinascimento which holds records for the City of Rome from 1871, including the German occupation and the roundup of the Roman Jews in October 1943. It is one of the basic tools of the historians' trade to know not only what questions to ask of the issue being investigated, but to

${ }^{5}$ See http://www.pacelli-edition.de/ and http://www.dhiroma.it/orsenigo.html

${ }^{6}$ Edgardo was born and raised Jewish until the age of 6 when he was taken away by papal authorities on the grounds that a domestic servant had baptised him in an 'emergency'. See http://www.historians.org/perspectives/issues/1999/9905/9905ar c1.cfm accessed 19.01.2009. 
know where and how to find resources and to be imaginative in seeking them.

For students of the Holocaust and the role the Catholic Church during the war years, there is an abundance of material readily available. Much of it has not been used well. One of the most important sources is the set of 11 volumes published by the Vatican. ${ }^{7}$

\section{Actes et Documents}

In the storm of anti-Pius criticism that arose after the 1963 opening of Rolf Hochhuth's play, The Deputy, Pope Paul VI took the extraordinary measure of commissioning four professional historians, all Jesuits, to sort and sift their way through the files of the Secretariat of State of Pius XII between 1939 and 1945. Their brief was to collate a selection of documents representative of the whole collection that would give as detailed a picture as possible of the work of the Pope and his closest collaborators, One of whom was Paul VI himself. Throughout the war years he worked in the Secretariat alongside the Secretary of State, Cardinal Luigi Maglione. Giovanni Batista Montini, the future Pope Paul, was privy to much of the confidential material that made its way to and from the Pope's desk. He was one of the last surviving eye-witnesses to the internal workings of the Vatican during the war years.

The four Jesuit historians - Pierre Blet (1918-2009, France), Angelo Martini (1913-1981, Italy), Burkhart Schneider (19171976, Germany), and Robert Graham (1912-1997, United States)-began their work in 1964 and published their findings as they completed each major historical and logical section. All were professional historians with significant published works in church history. It would be 
unprofessional to assert that there was a conspiracy operating among the four men as they selected documents for publication to 'whitewash' Pius and his war record. A cursory glance at the range of documents makes it all but impossible to accuse them of anything other than compiling a comprehensive portrait of the Vatican leadership trying to cope with the often horrific news streaming in from across Europe. When one looks at the documentation describing the plight of European Jewry, the picture assumes an even more desperate and dreadful visage.

\section{Structure of ADSS}

The Vatican Secretariat of State was not the equivalent of a foreign affairs ministry, but more akin to a combination of foreign affairs, prime minister and papal secretary. The Secretariat sent and received letters, telegrams, telephone calls, press clippings, summary tables, detailed reports, confidential personal files and notes concerning the internal life of the Church-for example, in matters of Canon Law, selection of bishops, requests for faculties (authority for bishops and heads of religious orders for the good-ordering of their dioceses, monasteries, and so on), as well as the religious life of the Church in areas like Catholic Action, the operation of charitable works, the Catholic press, schools and hospitals. The documents in ADSS reflect this.

1. The archives of the Secretary of State contain:

(a) messages and speeches of the Pope;

(b) letters exchanged between the Pope and religious and secular leaders;

(c) notes of the Secretary of State, private notes and memoranda;

(d) correspondence between the Secretary of State and nuncios, apostolic delegates and apostolic administrators; 
(e) correspondence between the Secretary of State and ambassadors and ministers accredited to the Holy See.

2. ADSS has published the selected texts in the following manner:

(a) The official addresses, speeches etc of Pius XII have been published in the Acta Apostolicae Sedis (1939-1958) or in the collection of the Pope's speeches published after his death. ${ }^{8}$ What is contained in ADSS are extracts relevant to a particular issue.

(b) ADSS has published some, but not many, of Pius' letters to religious and secular leaders.

(c) Memoranda of the Secretariat were composed after audiences with the Pope, meetings with ambassadors or a reflection on matters that may have required further action. These were written or typed by the Cardinal Secretary of State (up to 1944, Cardinal Luigi Maglione 1877-1944), Secretary of the Congregation of Extraordinary Ecclesiastical Affairs, Domenico Tardini, (1888-1961), the Substitute of the Secretariat of State, Giovanni Batista Montini (1897-1978).

3. The correspondence exchanged with the Holy See and its representative contains:

(a) original reports sent by nuncios et alii to the Secretariat;

(b) telegrams sent from nuncios etc to Cardinal Secretary of State and others by the department of telegrams and ciphers;

(c) drafts prepared for the nuncios;

(d) drafts of telegrams to be encoded.

ADSS has published the documents in chronological order,

8 AAS, or Acta, as it is commonly referred to, is available online via the Vatican website. See

http://www.vatican.va/archive/aas/index_en.htm 
which gives an accurate impression of the flow of information into and out of the Vatican. Each document is listed with its archive number and original form (handwritten or typed). Internal cross-referencing follows in the footnotes. The editors did not print documents available in other published collections but referred readers to the appropriate sources.

The vast majority of the documents are short reports, some as brief as one line. There are occasional detailed reports, but these are the exception. During war time, letter writing was more and more a luxury that was not indulged. Increasingly, the Vatican relied on sharp and concise communication. Lengthy reports were still sent and provide valuable information, but the time it took to reach Rome increased as the war went on, and could take as long as months when sent from Eastern Europe. This needs to be kept in mind when looking at Holocaust chronology and attempting to explain why a response sometimes took so long.

There are lacunae. Notable missing documents include most of the letters from Bishop Konrad Preysing of Berlin to Pius XII in 1943 and 1944, almost any reference to the 'brown bishop', Austrian Alois Hudal, the Riegner Report (which is mentioned but not published), ${ }^{9}$ the Auschwitz Protocols and virtually everything appertaining to Eastern Europe except for Poland and the Baltic States. Interestingly, there are few major details missing from reports concerning the killing of the Jews. It would appear that as news of the killing process became more widely known, and a sense of moral outrage on the part of some Vatican diplomats grew, especially those in Slovakia, Croatia and Hungary, the customary cautious language was replaced by something far blunter. It could also point to a sense of frustration at what could have been

\footnotetext{
9 ADSS, 8.314, 19.03.1942, Nuncio Filippo Bernardino to Cardinal Cardinal Maglione.
} 
perceived as the Vatican's delay in responding.

The 11 volumes were published between 1965 and 1981 . They include over 5,000 documents in original languages, (mostly Italian, the working language of the Vatican), many with footnotes and references to other published sources. A sentence synopsis of the text in French heads every document. Each volume has an introductory essay, also written in French, giving the main themes of the particular focus for that collection of documents as well as placing the documents within the broader context of the war. At the end of the first volume there are comprehensive appendices of the nuncios, internuncios and apostolic delegates who acted as the diplomatic representatives of the Pope across the world, giving a wealth of information on who was where and when. There is a detailed appendix of the diplomatic corps accredited to the Holy See, including the changes in personnel caused by the unpredictable nature of the war. In effect, the reader is given a considerable amount of help from the editors in order to better understand the documents.

Volumes 1, 4, 5, 7 and 11 contain documents about the Vatican and the prosecution of the war in Europe and later, the global conflict. Volumes 6, 8, 9 and 10 are devoted to the work of the Holy See and the victims of the war, including the Jews of Europe. Volume 2 contains a selection of the letters of Pius XII to the bishops of Germany. Some of the letters of the German bishops to Pius are found throughout the other volumes or in independent references. Volume 3 is divided into two parts that deal with the Vatican, Poland and the Baltic States - 'the East'. There is a detailed index (in French) at the end of each volume.

Within each volume there is evidence of considerable effort made to ensure a high level of continuity between the documents. One example from Volume 1 demonstrates this. In the final days before the German invasion of Poland on 1 September 1939, the Vatican was engaged in a major diplomatic effort to avoid war and bring Germany and 
Poland to the negotiating table. Cardinal Luigi Maglione, the Secretary of State, was in regular telegraphic, telephone and cable communication with the nuncios in Nand Warsaw as well as the other capitals of Europe listening and suggesting strategies to avoid a war. Throughout the documents there is a high level of Realpolitik about Hitler, the value of his promises and claims, and the webs of alliances between different states.

\section{ADSS 1.153}

In document 153 of 30 August 1939, Cardinal Maglione, the Secretary of State, directed Archbishop Filippo Cortesi, the Nuncio to Poland, to present to the President of Poland a proposal suggesting Poland 'return' Danzig to Germany in order to bring Hitler back to the negotiating table. Crossreferenced to this document are earlier documents that show the development of this instruction which, if left standing alone and without context, could lead to a highly negative assessment of the Holy See. The reader must also keep in mind that this 'string' of documents occurred during the last days of peace, when communication between Warsaw and Rome was free and unimpeded.

Document 102-18 August, Cortesi to Maglione: Polish government does not know what the Holy See can do to further peace; German troops are concentrated on the Pomeranian-German border;

Document 121-25 August, Cortesi to Maglione: the Polish government has given the secret order to mobilise all men up to 40 years of age in the border province next to East Prussia;

Document 125-26 August, Archbishop Cesare Orsenigo, Nuncio to Germany to Maglione: Germany is prepared for war with Poland but would prefer negotiation to settle problems; but be warned German honour has been insulted and they are prepared to fight;

Document 128-26 August, Maglione to Cortesi: Cortesi is to 
let the Polish government know that if they made some concession to Germany on the question of Danzig war could be avoided;

Document 135-27 August, Cortesi to Maglione: Polish government is afraid of any concessions to Germany;

Document 136-27 August, Cortesi to Maglione: added from document 135 that Poland is concerned that any move to granting concessions would suggest that German accusations of persecution of the German minority in Poland were true and the government knows too well Hitler's method of extending territorial claims through such accusations.

The outcome of all this manoeuvering came to nought; but Maglione, Cortesi, Orsenigo, and ultimately, the Pope, believed they had to make every attempt to work for peace. Perhaps the saddest and most poignant document that follows this example is the belated acknowledgement and thanks for the Pope's efforts given by the Polish government on 14 September, written three days before the Soviet Union invaded Poland from the east and two weeks before Warsaw finally capitulated..$^{10}$ In some respects, this example is atypical of much of the material. Conditions during wartime made correspondence difficult. There were 'grades' of difficulty. Diplomatic notes, letters and telegrams usually 'got through' with a minimum of interference, regardless of Axis or Allied origins. The glaring exceptions were Poland, the Baltic States (apart from the first Soviet occupation in 1940) and Germanoccupied Russia and Ukraine. Some letters from bishops in Lithuania and Ukraine could take several months to reach the Vatican; but Berlin Nuncio, Cesare Orsenigo, was still sending promptly delivered communiqués to Rome until late March 1945. There is, quite simply, no universal logic as to why some parts of German occupied Poland had virtually unrestricted communication with Rome and others had very limited

${ }_{10}$ ADSS, 1.201, 14 Sept 1939, Ambassador Casimir Papée to the Secretary of State. 
contact.

\section{External cross-referencing}

By the time the last volume of ADSS was published in 1981, the amount of edited and published wartime material available was staggering. It began in 1946 when the International Military Tribunal published the records of the Nuremburg Trials, providing a major source of primary material on the prosecution of the war in Europe with a particular focus on war crimes, especially the genocide of the Jews. Documents on British foreign policy 1918-1945 were published between 1949 and 1983; those of the United States had been published since 1932; and in 1957 the US Department of State published, in English, documents on German foreign policy between 1918 and 1945. Between 1953 and 2000, Italy published Volumes 6 through to 10 of Documenti Diplomatici Italiani which covered the Fascist era, the 1939-1943 war, and the German occupation and liberation. All of these collections contained significant references to the murder of the Jews of Europe at all stages of the genocide.

The ASV has continued its own research. A major documentary collection was published in 2004. The two volumes of Inter Arma Caritas: L'Ufficio Informazioni Vaticano per I Priginionieri de Guerra istituito da Pio XII (1939-1947) is one of the most significant works published in the area of war-relief work for prisoners of war and, despite the title, other victims of war, including Jews. ${ }^{11}$ Over three million records are contained in the collection. It is an impressive work and one that demands attention. It was released in both

11 (2004), 'Inter Arma Caritas: L’Ufficio Informazioni Vaticano per I Priginionieri de Guerra istituito da Pio XII' (1939-1947) 2 vols, Vatican City. 
book and CD form.

Since my focus here is on the documentary evidence found in ADSS, it is important to note some of the more important collections of Church archives from outside Rome. Chief among the published collections are works such as Dieter Albrecht's edited collection of the formal notes exchanged between the Vatican and Reich government, published between 1965 and 1980, practically contemporary with ADSS. ${ }^{12}$ This work has been complemented and expanded through the research work of Thomas Brechenmacher at the University of Potsdam. ${ }^{13}$ Another companion collection which appeared between 1968 and 1985 was the work of Bernhard Stasiewski and the six volumes recording the formal proceedings of the German bishops under the Third Reich. ${ }^{14}$ Of further contextual value are the growing number of published archival records of individual German bishops. The formidable 1975 Akten Kardinal Michael von Faulhaber 19171945, edited by Ludwig Volk, is just one example. ${ }^{15}$ In 2002, the entire Faulhaber archive was opened to researchers through the Munich Archdiocesan Archives. Since Cardinal Faulhaber was one of Pius XII's vital communication links to Germany during the war, the material in this particular archive is of particular importance.

12 Albrecht, Dieter (ed) (1965-1980), 'Der Notenwechsel zwischen dem Heiligen Stuhl und der Deutschen Reichsregierung', 3 vols, Matthias-Grünewald, Mainz.

${ }^{13}$ Brechenmacher, Thomas (2005), ‘Pope Pius XI, Eugenio Pacelli and the Persecution of the Jews in Nazi Germany, 1933-1939: New Sources from the Vatican Archives' in Bulletin of the German Historical Institute London, 27.2, 17-44.

14 Stasiewski, Bernhard (ed) (1968-1985), 'Akten Deutscher Bischöfe über die Lage der Kirche 1933-1945’, 6 vols, Matthias-GrünewaldVerlag, Mainz.

${ }_{15}$ Volk, Ludwig (ed) (1975), 2 vols, Matthias-Grünewald-Verlag, Mainz. 
A word of caution is necessary. Archives in many parts of Germany and Eastern Europe often did not survive the war or were very badly damaged. Nearly the entire archive of the Berlin Diocese and the Apostolic Nunciature was destroyed in air raids. This means that attempts to rebuild the activities of the diocese and the nunciature with regard to the 'Jewish Question' is made all the more difficult. What remains fills a few slender files. ${ }^{16}$ Maintenance of archives under Communism was not a high priority for the Church and while a lot of work has been done to centralise and record archival evidence, there is much that remains unexamined and much that is lost.

It is collections such as these that provide material to complement and sometimes challenge ADSS. One of the criticisms levelled at ADSS is what is not found in its pages. By using other published collections to cross-reference what is not found in ADSS, a more complete record is established. ADSS Volume 2 contains Pius' letters to the German bishops but it does not contain the letters they wrote to him. By using Stasiewski, the historian is able to reconstruct some of the correspondence. This is not the most satisfactory method, but until the remaining archives are opened in 2014, it may be the only method for the foreseeable future. Other sources are the hundreds of local diocesan and congregational archives that are often willing to allow researchers access to files. The work of Susan Zuccotti in Under His Very Windows is a case in point.

\section{Tracing the Holocaust}

In a collection as considerable as ADSS, the historian needs to look carefully for threads across the volumes. Simply looking for key words will not suffice. A general appreciation of the history of the war is essential in order to search effectively for

16 Thomas Brechenmacher to Paul O'Shea, 8 March 2009. 
the less than obvious antisemitic references or details about the 'non-Aryans'. The Vatican used the political language of the day, varying according to the government or diplomat it was dealing with. Circumspection when asking for details about concentration camp prisoners from the German Foreign Office was replaced with plain speaking when discussing the same matter with the personal representative of President Roosevelt. And while it is true that the Vatican was as wellinformed as either Roosevelt or Churchill, although in different ways and by different means, it is inaccurate to presume that the Pope's bureaucracy was a model of perfection-it was not. Mistakes were made; prejudices were present and confusion in reports sometimes meant the picture was obscured. But our purpose here is to point out what is present in ADSS. Interpretation of the documents is not the primary intention, even though some comment may be made.

What emerges very early in ADSS is the rapidly expanding scale of both the Vatican's attempts to help victims of the war and the requests made of the Holy See by governments and aid agencies, including Jewish communal and international groups. A statistical survey of ADSS demonstrates something of the Vatican's involvement in, and awareness of, the 'Jewish Question'. At the very least, the numbers point to an active concern to receive and transmit information, request information of governments and aid agencies as well as the internal structures of the Church across Europe and even as far afield as Shanghai where a group of refugee Polish rabbis waited while Rome attempted to broker a way for them to leave China.

Within Volumes 1, 2, 3, 4, 5, 7 and 11, the documents deal with 'conventional' war, the restrictions placed on the Church in different parts of German-occupied Europe and the constant discussions with bishops, nuncios, diplomats, heads of state and military leaders over issues that ranged from discussions over episcopal appointments to appeals to spare Rome from bombing. References to the Jews are more incidental-that they appear in 'conventional' documents 
illustrates the pervasive nature of Nazi antisemitism. Within these volumes there are close to 100 individual documents that mention Jews, Jewish suffering, antisemitism and German anti-Jewish atrocities. The following table sets out this information.

\section{Table 1}

\begin{tabular}{|l|l|l|c|}
\hline Vol & Title & Documents & $\begin{array}{l}\text { Specific } \\
\text { mention of } \\
\text { Jews }\end{array}$ \\
\hline 1 & War Mar 1939-Aug 1940 & 379 & 4 \\
\hline 2 & $\begin{array}{l}\text { Letters of Pius XII to } \\
\text { German bishops }\end{array}$ & 124 & 4 \\
\hline 3.1 & $\begin{array}{l}\text { Poland and the Baltic } \\
\text { Sates Feb 1939-Dec 1941 }\end{array}$ & 344 & 10 \\
\hline 3.2 & $\begin{array}{l}\text { Poland and the Baltic } \\
\text { States Jan 1942-May } \\
\text { 1946 }\end{array}$ & 261 & 6 \\
\hline 4 & War: Jun 1940 -Jun 1941 & 433 & 8 \\
\hline 5 & War: Jul 1941-Oct 1942 & 511 & 11 \\
\hline 7 & War: Nov 1942-Dec 1943 & 505 & 7 \\
\hline 11 & War: Jan 1944-May 1945 & 552 & 6 \\
\hline
\end{tabular}

The remaining Volumes, 6, 8, 9 and 10 deal with the victims of war. Here the number of documents that deal directly with 'non-Aryans' or 'Jews' and the events led up to and including the genocide of European Jewry are numbered in the hundreds. 
Table 2

\begin{tabular}{|l|l|l|l|}
\hline Vol & Title & Documents & $\begin{array}{l}\text { Specific } \\
\text { mention of } \\
\text { Jews }\end{array}$ \\
\hline 6 & Mar 1939-Dec 1940 & 419 & $154(36 \%)$ \\
\hline 8 & Jan 1941-Dec 1942 & 581 & $195(33.5 \%)$ \\
\hline 9 & Jan 1943-Dec 1943 & 492 & $205(41.6 \%)$ \\
\hline 10 & Jan 1944-Jul 1945 & 488 & $180(36.8 \%)$ \\
\hline
\end{tabular}

Of the 5,089 documents in ADSS, 734 (14.5 per cent) relate directly to the persecution and murder of the Jews.

What were matters that concerned Jews in particular that filled the documents sent to Rome? In brief, the documents refer to almost every aspect of Jewish life under German occupation. A detailed analysis of ADSS is beyond my scope here, but a tabulated excursus into the material concerning Slovakia in 1942 when the machinery and apparatus of the 'Final Solution' were in the process of refinement gives the reader a clear idea of what information Rome received and, more importantly, what were Rome's responses. The chronology that follows is taken directly from ADSS and attempts to show, across the volumes, what was known and what was done. Where necessary I have included external references.

\section{ADSS and the persecution of the Jews of Slovakia in 1942}

The year 1942 was the turning point for the Jews of Europe. Since the outbreak of war in September 1939, the European Jews who found themselves under German domination joined the Jews of Germany and Austria as the primary victims of Nazi violence. Dispossessed, despoiled and deported, walled up in ghettos, stripped of all legal protection, persecuted at whim and exploited as expendable slave labour, the Jews lived in a terrifying and murderous isolation from the rest of humanity. No other victim group of the Nazis was as isolated and vulnerable as the Jews-but, as the documents in the 
ADSS demonstrate, the isolation was not unknown, nor was the implementation of the 'Final Solution'. However, the Germans could not murder Europe's Jews without considerable co-operation from non-German sources. Centuries of Christian Jew-hatred and its more virulent mutation, racial antisemitism, meant that the Berlin 'desk killers' did not have to look far to find willing accomplices. The government of Slovakia was not slow to mimic their German overlords. And the Vatican's diplomats reported regularly, and with a high degree of accuracy, the gradual process of dispossession, deportation and disappearance of the Jews.

Slovakia was different from every other country in Europe both before and during the war. Created from the dismembered Czechoslovak republic in 1939, the right-wing government was given permission by Hitler to declare itself independent-which it certainly was not as far as Germany was concerned. Its head of state was a Catholic priest, Josef Tiso, and its governing ideology was a mix of Catholic restorationism and nationalism mixed with an adapted German-style fascism, which included a vicious hatred of Jews. The Vatican looked askance at Tiso the priest in politics, not so much the politics itself. ${ }^{17}$ When the Slovakian parliament passed anti-Jewish laws in September 1941, the papal Chargé d'affaires, Monsignor Giuseppe Burzio, was instructed to protest. ${ }^{18}$ Maglione summoned the Slovakian minister in Rome, Karel Sidor, and expressed his anger at the

17 Cf ADSS 4.52, Burzio to Maglione, 21 September 1940, note 2. Tardini had been instructed on 12 November 1939 to write to Orsenigo in Berlin telling his to find a way to let Tiso know of the Vatican's displeasure at his appointment as President. ${ }^{18}$ ADSS 8.153, Burzio to Maglione 18 September 1941. 
passing of the laws. ${ }^{19}$ The protest did nothing to stop preparations for deportations that were planned for March 1942.

On 26 March 1942, the first transport of 999 Slovakian Jewish girls and women left Bratislava for Auschwitz. Since the passing of the anti-Jewish laws six months earlier, Tiso's government had progressively impoverished the Jews of Slovakia, stolen and 'Aryanised' their businesses, pushed them out of the professions and industry and effectively made them paupers. It made economic sense to deport them. Prime Minister Vojtekh Tuka offered the Germans 20,000 Jews for forced labour outside Slovakia. Adolf Eichmann accepted the offer. He needed more workers for the building projects at Birkenau and nearly all the Soviet prisoners who had slaved on the new camp had been worked to death. Tuka also offered to pay RM500 per Jew on condition that they never return to Slovakia and their property forfeited to the Slovakian state. Eichmann agreed.

Between March and June 1942, 52,000 Jews were deported-most of them to Auschwitz-Birkenau. After June, the deportations slowed largely due to the interventions made through the Vatican's representative in Bratislava, Monsignor Giuseppe Burzio, not the Slovakian bishops, many of whom remained, if not hostile to Jews, then indifferent to their fate. The Slovakian minister to the Holy See, Karel Sidor, was also under pressure from Cardinal Maglione who spoke in the Pope's name. The Holy Father wanted the trains stopped. And stopped they were for several months before resuming at a slower rate in September.

Once the Vatican view was known among the Slovak bishops, attitudes began to change slowly. A pastoral letter written in April spoke of the right of the Jews to humane treatment based on civil and natural law while at the same

${ }_{19}$ ADSS 8.199, Maglione to Sidor, 12 November 1941. 
time berating them for killing Christ. The German minister in Bratislava, Hans Ludin, complained to Berlin that deportations were slowing because of the interference of the Church which had granted, with government approval, exemptions for at least 20,000 baptised Jews, more exemptions approved by the government for at least another 15,000 Jews, and the corruption of individual officials. For tactical reasons, Himmler and Eichmann accepted the deadlock, but only as a temporary measure. The Jews of Slovakia were slated for death in the same way that every other Jew in Europe was doomed to be murdered. Transports resumed in the autumn of 1944 in the wake of the failed partisan uprising.

The following table sets out in chronological order the documents found in ADSS that deal with Slovakia in 1942. It is important to keep in mind that the information contained in each document was as accurate a record as possible at the time and is, in itself, a valuable indicator of the different types of information available - some true and some not.

\section{Table 3}

ADSS Chronology of the Persecution of the Jews of
Slovakia 1942




\begin{tabular}{|c|c|c|c|c|}
\hline & & & & of baptised Jews. \\
\hline $\begin{array}{l}8 . \\
184\end{array}$ & $\begin{array}{l}27 \\
\text { Oct } \\
1941\end{array}$ & $\begin{array}{l}\text { Giuseppe } \\
\text { Burzio }\end{array}$ & $\begin{array}{l}\text { Cardinal } \\
\text { Maglione }\end{array}$ & $\begin{array}{l}\text { Reports inhuman } \\
\text { treatment of } \\
\text { Russian POWs and } \\
\text { Jews imprisoned in } \\
\text { eastern Slovakia. }\end{array}$ \\
\hline $\begin{array}{l}8 . \\
199\end{array}$ & $\begin{array}{l}12 \\
\text { Nov } \\
1941\end{array}$ & $\begin{array}{l}\text { Cardinal } \\
\text { Maglione }\end{array}$ & $\begin{array}{l}\text { Karel } \\
\text { Sidor, } \\
\text { Slovakian } \\
\text { Minister } \\
\text { to the } \\
\text { Holy See }\end{array}$ & $\begin{array}{l}\text { Reports on Vatican } \\
\text { objections to racial } \\
\text { legislation in Slova- } \\
\text { kia: asserts right of } \\
\text { Church to regulate } \\
\text { marriage including } \\
\text { mixed marriages } \\
\text { and rights of } \\
\text { baptised Jews. The } \\
\text { Holy See cannot be } \\
\text { indifferent to this. }\end{array}$ \\
\hline $\begin{array}{l}8 . \\
298\end{array}$ & $\begin{array}{l}09 \\
\text { Mar } \\
1942\end{array}$ & $\begin{array}{l}\text { Giuseppe } \\
\text { Burzio }\end{array}$ & $\begin{array}{l}\text { Cardinal } \\
\text { Maglione }\end{array}$ & $\begin{array}{l}\text { Reports that deport- } \\
\text { ation of Slovakian } \\
\text { Jews to Galicia and } \\
\text { Lublin region immi- } \\
\text { nent. At end of } \\
\text { report Burzio } \\
\text { wrote: 'The deport- } \\
\text { ation of } 80,000 \\
\text { people to Poland at } \\
\text { the mercy of the } \\
\text { Germans is equiva- } \\
\text { lent to condemning } \\
\text { the greater part to } \\
\text { certain death.' }\end{array}$ \\
\hline $\begin{array}{l}8 . \\
300\end{array}$ & $\begin{array}{l}10 \\
\text { Mar } \\
1942\end{array}$ & $\begin{array}{l}\text { Filippo } \\
\text { Bernadini } \\
\text { - Nuncio } \\
\text { Switzer- } \\
\text { land }\end{array}$ & $\begin{array}{l}\text { Cardinal } \\
\text { Maglione }\end{array}$ & $\begin{array}{l}\text { Reports received } \\
\text { from Caritas } \\
\text { Switzerland and } \\
\text { Agudas Israel indi- } \\
\text { cate deportation of } \\
\text { 135,000 Slovakian }\end{array}$ \\
\hline
\end{tabular}




\begin{tabular}{|c|c|c|c|c|}
\hline & & & & $\begin{array}{l}\text { Jews to begin } 23 \\
\text { March } 1942 .\end{array}$ \\
\hline $\begin{array}{l}8 . \\
301\end{array}$ & $\begin{array}{l}11 \\
\text { Mar } \\
1942\end{array}$ & $\begin{array}{l}\text { Giuseppe } \\
\text { Burzio }\end{array}$ & $\begin{array}{l}\text { Cardinal } \\
\text { Maglione }\end{array}$ & $\begin{array}{l}\text { Reports received } \\
\text { from Slovakian } \\
\text { military chaplains } \\
\text { tell of SS led } \\
\text { [Einsatzgruppen] } \\
\text { massacres of Jews } \\
\text { in German occupied } \\
\text { Russia. }\end{array}$ \\
\hline $\begin{array}{l}8 . \\
303\end{array}$ & $\begin{array}{l}13 \\
\text { Mar } \\
1942\end{array}$ & $\begin{array}{l}\text { Angelo } \\
\text { Rotta, } \\
\text { Nuncio } \\
\text { Hungary }\end{array}$ & $\begin{array}{l}\text { Cardinal } \\
\text { Maglione }\end{array}$ & $\begin{array}{l}\text { Appeal for papal } \\
\text { intervention for } \\
\text { Slovakian Jews } \\
\text { threatened with } \\
\text { expulsion to Poland } \\
\text { with attached } \\
\text { appeal from Jewish } \\
\text { Community of } \\
\text { Bratislava: 'We are } \\
\text { condemned to } \\
\text { destruction.' }\end{array}$ \\
\hline $\begin{array}{l}8 . \\
305\end{array}$ & $\begin{array}{l}14 \\
\text { Mar } \\
1942\end{array}$ & $\begin{array}{l}\text { Cardinal } \\
\text { Maglione }\end{array}$ & $\begin{array}{l}\text { Karel } \\
\text { Sidor, } \\
\text { Slovak }\end{array}$ & $\begin{array}{l}\text { Informs Sidor of re- } \\
\text { ports of imminent } \\
\text { expulsion of } 80,000 \\
\text { Jews to Galicia and } \\
\text { Lublin region. Ex- } \\
\text { presses hope that } \\
\text { information untrue. }\end{array}$ \\
\hline $\begin{array}{l}8 . \\
312\end{array}$ & $\begin{array}{l}19 \\
\text { Mar } \\
1942 \\
\end{array}$ & $\begin{array}{l}\text { Cardinal } \\
\text { Maglione }\end{array}$ & $\begin{array}{l}\text { Filippo } \\
\text { Bernar- } \\
\text { dini }\end{array}$ & $\begin{array}{l}\text { Instructions for } \\
\text { intervention for } \\
\text { Slovakian Jews. }\end{array}$ \\
\hline $\begin{array}{l}8 . \\
314\end{array}$ & $\begin{array}{l}19 \\
\text { Mar } \\
1942\end{array}$ & $\begin{array}{l}\text { Filippo } \\
\text { Bernar- } \\
\text { dini }\end{array}$ & $\begin{array}{l}\text { Cardinal } \\
\text { Maglione }\end{array}$ & $\begin{array}{l}\text { Report on situation } \\
\text { of Jews of Central } \\
\text { Europe-enclosed } \\
\text { in report was }\end{array}$ \\
\hline
\end{tabular}




\begin{tabular}{|c|c|c|c|c|}
\hline & & & & $\begin{array}{l}\text { Riegner telegram - } \\
\text { response made Doc } \\
322\end{array}$ \\
\hline $\begin{array}{l}8 . \\
317\end{array}$ & $\begin{array}{l}20 \\
\text { Mar } \\
1942\end{array}$ & $\begin{array}{l}\text { Angelo } \\
\text { Rotta }\end{array}$ & $\begin{array}{l}\text { Cardinal } \\
\text { Maglione }\end{array}$ & $\begin{array}{l}\text { Appeal for inter- } \\
\text { vention for Slova- } \\
\text { kian Jews to be de- } \\
\text { ported to Galicia } \\
\text { made by Chief } \\
\text { Rabbi of Budapest. } \\
\text { Response made Doc } \\
322\end{array}$ \\
\hline $\begin{array}{l}8 . \\
322\end{array}$ & $\begin{array}{l}24 \\
\text { Mar } \\
1942\end{array}$ & $\begin{array}{l}\text { Giovanni } \\
\text { Montini, } \\
\text { Secre- } \\
\text { tariat of } \\
\text { State, } \\
\text { note }\end{array}$ & & $\begin{array}{l}\text { Pius XII agreed to } \\
\text { discuss the matter } \\
\text { with Slovakian } \\
\text { minister. }\end{array}$ \\
\hline $\begin{array}{l}8 . \\
324\end{array}$ & $\begin{array}{l}24 \\
\text { Mar } \\
1942\end{array}$ & $\begin{array}{l}\text { Giuseppe } \\
\text { Burzio }\end{array}$ & $\begin{array}{l}\text { Cardinal } \\
\text { Maglione }\end{array}$ & $\begin{array}{l}\text { Reports deportation } \\
\text { of Slovak Jews sus- } \\
\text { pended because of } \\
\text { intervention of } \\
\text { Holy See. However, } \\
\text { one transport left } \\
\text { last night-girls } \\
\text { aged 16-25. Rum- } \\
\text { oured to be sent to } \\
\text { Russian front as } \\
\text { prostitutes - all } 999 \\
\text { gassed on arrival at } \\
\text { Auschwitz. }\end{array}$ \\
\hline $\begin{array}{l}8 . \\
326\end{array}$ & $\begin{array}{l}25 \\
\text { Mar } \\
1942\end{array}$ & $\begin{array}{l}\text { Giuseppe } \\
\text { Burzio }\end{array}$ & $\begin{array}{l}\text { Cardinal } \\
\text { Maglione }\end{array}$ & $\begin{array}{l}\text { Reports govern- } \\
\text { ment has not aban- } \\
\text { doned plans to } \\
\text { deport Slovak Jews } \\
\text { as reported yester- } \\
\text { day. First group } \\
\text { was sent. Men and }\end{array}$ \\
\hline
\end{tabular}




\begin{tabular}{|l|l|l|l|l|}
\hline $\begin{array}{l}\text { 8. } \\
328\end{array}$ & $\begin{array}{l}25 \\
\text { Mar } \\
1942\end{array}$ & $\begin{array}{l}\text { D'Arcy } \\
\text { Osborne, } \\
\text { UK } \\
\text { Minister } \\
\text { to Holy } \\
\text { See }\end{array}$ & $\begin{array}{l}\text { Cardinal } \\
\text { Maglione }\end{array}$ & $\begin{array}{l}\text { women - 10 000 to } \\
\text { be deported. }\end{array}$ \\
\hline $\begin{array}{l}\text { Appeal to Holy See } \\
\text { to intervene with } \\
\text { Tiso in favour of } \\
\text { 90,000 Slovak Jews, } \\
\text { especially those in } \\
\text { ghettos close to } \\
\text { Polish border. }\end{array}$ \\
\hline 832 & $\begin{array}{l}27 \\
\text { Mar }\end{array}$ & $\begin{array}{l}\text { Cardinal } \\
\text { Maglione }\end{array}$ & $\begin{array}{l}\text { Giuseppe } \\
\text { Burzio }\end{array}$ & $\begin{array}{l}\text { Maglione asked } \\
\text { Sidor to intervene } \\
\text { with his govern- } \\
\text { ment to stop depor- } \\
\text { tations. Burzio } \\
\text { instructed to appeal } \\
\text { to Tiso as a priest. }\end{array}$ \\
\hline 334 & $\begin{array}{l}\text { Mar } \\
1942\end{array}$ & $\begin{array}{l}\text { Giuseppe } \\
\text { Burzio }\end{array}$ & $\begin{array}{l}\text { Cardinal } \\
\text { Maglione }\end{array}$ & $\begin{array}{l}\text { Reports deportation } \\
\text { of Jews begun and } \\
\text { conducted with } \\
\text { great brutality. } \\
\text { Government claims } \\
\text { it is in accord with } \\
\text { the Church. Bishop } \\
\text { Vojtaššk urged } \\
\text { Church authorities } \\
\text { not to create prob- } \\
\text { lems for the govern- } \\
\text { ment or president } \\
\text { of the republic, for } \\
\text { Jews were the great- } \\
\text { est enemies of } \\
\text { Slovakia, and things } \\
\text { should be allowed } \\
\text { to run their course' }\end{array}$ \\
\hline
\end{tabular}




\begin{tabular}{|c|c|c|c|c|}
\hline $\begin{array}{l}8 . \\
342\end{array}$ & $\begin{array}{l}09 \\
\text { Apr } \\
1942\end{array}$ & $\begin{array}{l}\text { Filippo } \\
\text { Bernar- } \\
\text { dini }\end{array}$ & $\begin{array}{l}\text { Cardinal } \\
\text { Maglione }\end{array}$ & $\begin{array}{l}\text { Reports gratitude of } \\
\text { World Jewish Con- } \\
\text { gress for steps taken } \\
\text { in favour of Slovak } \\
\text { Jews. }\end{array}$ \\
\hline $\begin{array}{l}8 . \\
343\end{array}$ & $\begin{array}{l}09 \\
\text { Apr } \\
1942\end{array}$ & $\begin{array}{l}\text { Giuseppe } \\
\text { Burzio }\end{array}$ & $\begin{array}{l}\text { Cardinal } \\
\text { Maglione }\end{array}$ & $\begin{array}{l}\text { Reports that depor- } \\
\text { tation of Slovak } \\
\text { Jews continues; } \\
\text { Jews fleeing to } \\
\text { Hungary, brutal } \\
\text { scenes. }\end{array}$ \\
\hline $\begin{array}{l}8 . \\
345 \\
346\end{array}$ & $\begin{array}{l}11 \\
\text { Apr } \\
1942\end{array}$ & $\begin{array}{l}\text { Cardinal } \\
\text { Maglione } \\
\text { note }\end{array}$ & & $\begin{array}{l}\text { Vatican protest over } \\
\text { deportation of } \\
\text { Slovak Jews made } \\
\text { to Slovak minister } \\
\text { Karel Sidor, who } \\
\text { attempted to justify } \\
\text { deportations. }\end{array}$ \\
\hline $\begin{array}{l}8 . \\
352\end{array}$ & $\begin{array}{l}17 \\
\text { Apr } \\
1942\end{array}$ & $\begin{array}{l}\text { Angelo } \\
\text { Rotta }\end{array}$ & $\begin{array}{l}\text { Cardinal } \\
\text { Maglione }\end{array}$ & $\begin{array}{l}\text { Reports information } \\
\text { on Slovak Jews } \\
\text { relayed through } \\
\text { Hungarian woman } \\
\text { who has impression } \\
\text { that Pope's inter- } \\
\text { vention has had } \\
\text { effect on Tiso. She } \\
\text { spoke highly of } \\
\text { Burzio who, though } \\
\text { isolated, was man } \\
\text { of courage. }\end{array}$ \\
\hline $\begin{array}{l}8 . \\
354\end{array}$ & $\begin{array}{l}18 \\
\text { Apr } \\
1942\end{array}$ & $\begin{array}{l}\text { Cardinal } \\
\text { Maglione }\end{array}$ & $\begin{array}{l}\text { Giuseppe } \\
\text { Burzio }\end{array}$ & $\begin{array}{l}\text { Sends account of } \\
\text { Vatican protest to } \\
\text { Slovak minister - } 11 \\
\text { Apr - see } 334,346 .\end{array}$ \\
\hline
\end{tabular}




\begin{tabular}{|c|c|c|c|c|}
\hline $\begin{array}{l}8 . \\
360\end{array}$ & $\begin{array}{l}27 \\
\text { Apr } \\
1942\end{array}$ & $\begin{array}{l}\text { Giuseppe } \\
\text { Burzio }\end{array}$ & $\begin{array}{l}\text { Cardinal } \\
\text { Maglione }\end{array}$ & $\begin{array}{l}\text { Sends copy of the } \\
\text { letter of Slovak } \\
\text { bishops concerning } \\
\text { racial laws. Baptism } \\
\text { is only sure way for } \\
\text { Jews to reach safety. }\end{array}$ \\
\hline $\begin{array}{l}8 . \\
364\end{array}$ & $\begin{array}{l}01 \\
\text { May } \\
1942\end{array}$ & $\begin{array}{l}\text { Angelo } \\
\text { Rotta }\end{array}$ & $\begin{array}{l}\text { Cardinal } \\
\text { Maglione }\end{array}$ & $\begin{array}{l}\text { Sends letter from Fr } \\
\text { Pozdech in Slovakia } \\
\text { to President of Jew- } \\
\text { ish Community in } \\
\text { Budapest appeal- } \\
\text { ing for world wide } \\
\text { condemnation of } \\
\text { persecution of Jews }\end{array}$ \\
\hline $\begin{array}{l}8 . \\
368\end{array}$ & $\begin{array}{l}07 \\
\text { May } \\
1942\end{array}$ & $\begin{array}{l}\text { Babuscio } \\
\text { Rizzo, } \\
\text { Counsel- } \\
\text { lor of the } \\
\text { Italian } \\
\text { Embassy }\end{array}$ & $\begin{array}{l}\text { Holy See; } \\
\text { notes }\end{array}$ & $\begin{array}{l}\text { Declaration of } \\
\text { Slovak government } \\
\text { concerning racial } \\
\text { legislation -'the } \\
\text { definitive decision } \\
\text { for the total resol- } \\
\text { ution of the Jewish } \\
\text { problem... baptised } \\
\text { or not, all the Jews } \\
\text { must be removed.' }\end{array}$ \\
\hline $\begin{array}{l}8 . \\
382\end{array}$ & $\begin{array}{l}23 \\
\text { May } \\
1942\end{array}$ & $\begin{array}{l}\text { Giuseppe } \\
\text { Burzio }\end{array}$ & $\begin{array}{l}\text { Cardinal } \\
\text { Maglione }\end{array}$ & $\begin{array}{l}\text { Reports on newly } \\
\text { passed retroactive } \\
\text { law to legalise de- } \\
\text { portations and } \\
\text { stripping of citizen- } \\
\text { ship of Jews. }\end{array}$ \\
\hline $\begin{array}{l}8 . \\
383\end{array}$ & $\begin{array}{l}23 \\
\text { May } \\
1942\end{array}$ & $\begin{array}{l}\text { Karel } \\
\text { Sidor }\end{array}$ & $\begin{array}{l}\text { Cardinal } \\
\text { Maglione }\end{array}$ & $\begin{array}{l}\text { Provides justifica- } \\
\text { tion for new anti- } \\
\text { Jewish laws in } \\
\text { Slovakia. Laws } \\
\text { necessary to resolve }\end{array}$ \\
\hline
\end{tabular}




\begin{tabular}{|c|c|c|c|c|}
\hline & & & & $\begin{array}{l}\text { serious 'Jewish } \\
\text { Quest-ion' in } \\
\text { Slovakia. European } \\
\text { solution is to settle } \\
\text { Jews outside Aryan } \\
\text { areas. }\end{array}$ \\
\hline $\begin{array}{l}8 . \\
389\end{array}$ & $\begin{array}{l}02 \\
\text { Jun } \\
1942\end{array}$ & $\begin{array}{l}\text { Rabbi } \\
\text { Joseph } \\
\text { Hermann } \\
\text { Hertz, } \\
\text { Chief } \\
\text { Rabbi of } \\
\text { British } \\
\text { Empire }\end{array}$ & $\begin{array}{l}\text { Cardinal } \\
\text { Maglione }\end{array}$ & $\begin{array}{l}\text { Appeals to the Holy } \\
\text { See for Slovak Jews. }\end{array}$ \\
\hline $\begin{array}{l}8 . \\
400\end{array}$ & $\begin{array}{l}19 \\
\text { Jun } \\
1942\end{array}$ & $\begin{array}{l}\text { Cardinal } \\
\text { Maglione }\end{array}$ & $\begin{array}{l}\text { Giuseppe } \\
\text { Burzio }\end{array}$ & $\begin{array}{l}\text { Instruction to con- } \\
\text { vey to the govern- } \\
\text { ment that the Holy } \\
\text { See deplores racial } \\
\text { legislation in Slo- } \\
\text { vakia, 'which was } \\
\text { passed with the } \\
\text { participation of } \\
\text { various priests, } \\
\text { deputies of the } \\
\text { Parliament.' }\end{array}$ \\
\hline $\begin{array}{l}8 . \\
426\end{array}$ & $\begin{array}{l}13 \\
\text { Jul } \\
1942\end{array}$ & $\begin{array}{l}\text { Domen- } \\
\text { ico } \\
\text { Tardini, } \\
\text { Secreta- } \\
\text { riat of } \\
\text { State; } \\
\text { notes }\end{array}$ & & $\begin{array}{l}\text { Concerning Slovak } \\
\text { Jews and frustration } \\
\text { with Tiso. }\end{array}$ \\
\hline $\begin{array}{l}8 . \\
430 \\
431\end{array}$ & $\begin{array}{l}17 \\
\text { Jul } \\
1942\end{array}$ & $\begin{array}{l}\text { Giuseppe } \\
\text { Marcone, } \\
\text { Papal } \\
\text { Represen- } \\
\text { tative, }\end{array}$ & $\begin{array}{l}\text { Cardinal } \\
\text { Maglione }\end{array}$ & $\begin{array}{l}\text { Reports difficulty } \\
\text { trying to obtain } \\
\text { information regard- } \\
\text { ing Croatian Jews. } \\
\text { Estimates up to two }\end{array}$ \\
\hline
\end{tabular}




\begin{tabular}{|c|c|c|c|c|}
\hline & & Croatia & & $\begin{array}{l}\text { million Jews have } \\
\text { been murdered. }\end{array}$ \\
\hline $\begin{array}{l}8 . \\
471\end{array}$ & $\begin{array}{l}10 \\
\text { Sep } \\
1942\end{array}$ & $\begin{array}{l}\text { Calliste } \\
\text { Lopinot, } \\
\text { OFM Cap }\end{array}$ & $\begin{array}{l}\text { Francesco } \\
\text { Borgon- } \\
\text { gini Duca, } \\
\text { Nuncio } \\
\text { Italy }\end{array}$ & $\begin{array}{l}\text { Reports that news is } \\
\text { reaching internees } \\
\text { in Ferramonti tell- } \\
\text { ing of massive de- } \\
\text { portations of Jews } \\
\text { from Germany and } \\
\text { France to places in } \\
\text { Poland. Jews with } \\
\text { family members in } \\
\text { Slovakia, Germany, } \\
\text { Holland and France } \\
\text { are understandably } \\
\text { worried. }\end{array}$ \\
\hline $\begin{array}{l}8 . \\
492\end{array}$ & $\begin{array}{l}26 \\
\text { Sep } \\
1942\end{array}$ & $\begin{array}{l}\text { Italian } \\
\text { Embassy }\end{array}$ & & $\begin{array}{l}\text { Information on } \\
\text { persecution of Jews } \\
\text { in Slovakia; estim- } \\
\text { ates } 70,000 \text { Jews } \\
\text { deported; } 16-20,000 \\
\text { remain because of } \\
\text { exemptions. }\end{array}$ \\
\hline $\begin{array}{l}8 . \\
493\end{array}$ & $\begin{array}{l}27 \\
\text { Sep } \\
1942\end{array}$ & $\begin{array}{l}\text { Giovanni } \\
\text { Montini, } \\
\text { Secreta- } \\
\text { riat of } \\
\text { State, } \\
\text { notes }\end{array}$ & & $\begin{array}{l}\text { On } 26 \text { September, } \\
\text { Myron Taylor } \\
\text { delivered the most } \\
\text { graphic report of } \\
\text { the killing of the } \\
\text { Jews to Cardinal } \\
\text { Maglione. }\end{array}$ \\
\hline $\begin{array}{l}8 . \\
496\end{array}$ & $\begin{array}{l}01 \\
\text { Oct } \\
1942\end{array}$ & $\begin{array}{l}\text { Giovanni } \\
\text { Montini }\end{array}$ & & $\begin{array}{l}\text { Information on } \\
\text { massacre of Jews. } \\
\text { Record of } \\
\text { Tittmann's } \\
\text { audience with Pius } \\
\text { XII -26 Sept } 1942 .\end{array}$ \\
\hline
\end{tabular}




\begin{tabular}{|c|c|c|c|c|}
\hline $\begin{array}{l}8 . \\
497\end{array}$ & $\begin{array}{l}03 \\
\text { Oct } \\
1942\end{array}$ & $\begin{array}{l}\text { Casimir } \\
\text { Papée } \\
\text { Polish } \\
\text { Ambass- } \\
\text { ador to } \\
\text { Holy See; } \\
\text { notes }\end{array}$ & & $\begin{array}{l}\text { News of massacres } \\
\text { of Jews in Poland - } \\
\text { Vilna ghetto (from } \\
80,000 \text { to } 12,000 \text { ), } \\
\text { Warsaw Ghetto } \\
\text { (methodical empty- } \\
\text { ing of the ghetto) } \\
\text { deportations to } \\
\text { Lublin; death by } \\
\text { asphyxiation. }\end{array}$ \\
\hline 7.53 & $\begin{array}{l}14 \\
\text { Dec } \\
1942\end{array}$ & $\begin{array}{l}\text { Cardinal } \\
\text { Maglione, } \\
\text { notes }\end{array}$ & & $\begin{array}{l}\text { After discussing } \\
\text { concerns about } \\
\text { bombing of civilian } \\
\text { targets, D'Arcy } \\
\text { Osborne, UK Minis- } \\
\text { ter to Holy See } \\
\text { asked 'But why has } \\
\text { the Holy See not } \\
\text { intervened against } \\
\text { the terrible massa- } \\
\text { cre of the Jews?' }\end{array}$ \\
\hline $\begin{array}{l}8 . \\
573\end{array}$ & $\begin{array}{l}19 \\
\text { Dec } \\
1942\end{array}$ & $\begin{array}{l}\text { Casimir } \\
\text { Papée }\end{array}$ & $\begin{array}{l}\text { Cardinal } \\
\text { Maglione }\end{array}$ & $\begin{array}{l}\text { Reports information } \\
\text { on extermination of } \\
\text { Jews in Poland, } \\
\text { including reports of } \\
\text { the 'liquidation' of } \\
\text { the Warsaw Ghetto. }\end{array}$ \\
\hline $\begin{array}{l}8 . \\
575\end{array}$ & $\begin{array}{l}23 \\
\text { Dec } \\
1942\end{array}$ & $\begin{array}{l}\text { Rabbi } \\
\text { Joseph } \\
\text { Hermann } \\
\text { Hertz, } \\
\text { Chief } \\
\text { Rabbi of } \\
\text { British } \\
\text { Empire }\end{array}$ & Pius XII & $\begin{array}{l}\text { Appeals to the Pope } \\
\text { to speak out against } \\
\text { the murder of the } \\
\text { Jews. }\end{array}$ \\
\hline 8. & 28 & Cardinal & Amleto & Response to 575- \\
\hline
\end{tabular}




\begin{tabular}{|l|l|l|l|l|}
\hline 577 & $\begin{array}{l}\text { Dec } \\
1942\end{array}$ & Maglione & $\begin{array}{l}\text { Cicognani } \\
\text {-Apostolic } \\
\text { Delegate, } \\
\text { USA }\end{array}$ & $\begin{array}{l}\text { Holy Father doing } \\
\text { all possible. }\end{array}$ \\
\hline
\end{tabular}

\section{KL Auschwitz}

Another example is to trace the growing awareness of Auschwitz in ADSS. The history of Auschwitz-Birkenau demonstrates the measure of success the Germans had in cloaking the real purpose of their premier permanent killing centre from both its intended victims - the Jews of Europeand those regarded in the Nazi Weltanschauung as racially equal or near enough to warrant the granting of the right to live. This did not include the racially undesirable such as Poles, Slavs or the Roma or Sinti peoples. While the number of direct references to Auschwitz/Oswiecim are relatively few, the details contained demonstrate a growing awareness of the scale of the killing process and the recognition by 1944 that Jews were sent there to die. The greater number of references occurs during the deportation of the Hungarian Jews in 1944.

The table sets out the information about Auschwitz as it was received and understood at the time. It is for the historian to contextualise the material into the broader narrative.

\section{Table 4:}

\begin{tabular}{|l|l|l|l|l|}
\hline \multicolumn{4}{|c|}{ ADSS References to Auschwitz in ADSS } \\
\hline Ref & Date & Ref & To & Details \\
\hline 3.1. & 02 & Cesare & Cardinal & Situation in Poland \\
208 & $\begin{array}{l}\text { Oct } \\
\text { is terrible. Priests } \\
\text { Orsenigo, } \\
\text { Luncio to } \\
\text { Germany }\end{array}$ & $\begin{array}{l}\text { Maglione, } \\
\text { Secretary } \\
\text { of State }\end{array}$ & $\begin{array}{l}\text { arrested and depor- } \\
\text { ted to concentration } \\
\text { camps. Nine Vin- } \\
\text { centian priests in } \\
\text { Krakow were }\end{array}$ \\
\hline
\end{tabular}




\begin{tabular}{|c|c|c|c|c|}
\hline & & & & $\begin{array}{l}\text { arrested and sent to } \\
\text { KL Auschwitz. }{ }^{20} \\
\text { Two already dead. }\end{array}$ \\
\hline $\begin{array}{l}7 . \\
82\end{array}$ & $\begin{array}{l}02 \\
\text { Jan } \\
1943\end{array}$ & $\begin{array}{l}\text { Polish } \\
\text { President } \\
\text { Raczkie- } \\
\text { wicz, in } \\
\text { exile in } \\
\text { London }\end{array}$ & Pius XII & $\begin{array}{l}\text { Requests word from } \\
\text { the Pope for Poland } \\
\text { and in response to } \\
\text { 'extermination of } \\
\text { the Jews and with } \\
\text { them many Christ- } \\
\text { ians of the Semitic } \\
\text { race who are sys- } \\
\text { tematically and } \\
\text { scientifically mur- } \\
\text { dered.' Mentions } \\
\text { Oswiecim } \\
\text { (Auschwitz). }\end{array}$ \\
\hline $\begin{array}{l}7 . \\
93\end{array}$ & $\begin{array}{l}22 \\
\text { Jan } \\
1943\end{array}$ & Orsenigo & Maglione & $\begin{array}{l}\text { Situation of Church } \\
\text { in Bohemia; priests } \\
\text { condemned to } \\
\text { death or imprison- } \\
\text { ed (KL Dachau, KL } \\
\text { Auschwitz, KL } \\
\text { Mauthausen, } \\
\text { Lidice, Prague. }\end{array}$ \\
\hline $\begin{array}{l}9 . \\
442\end{array}$ & $\begin{array}{l}27 \\
\text { Nov } \\
1943\end{array}$ & Maglione & Orsenigo & $\begin{array}{l}\text { Urgent request for } \\
\text { help for Cecilia } \\
\text { Mikołajczyk, wife of } \\
\text { Polish Prime Minis- } \\
\text { ter, arrested and } \\
\text { sent to KL Oswie- } \\
\text { cim. Thefirst time } \\
\text { name 'Oswiecim' }\end{array}$ \\
\hline
\end{tabular}

${ }^{20} \mathrm{KL}=$ Konzentrationslager, 'concentration camp'. This abbreviation or 'KZ' were commonly used. 


\begin{tabular}{|c|c|c|c|c|}
\hline & & & & $\begin{array}{l}\text { appears in } \\
\text { document origina- } \\
\text { ting from the } \\
\text { Vatican in ADSS. }\end{array}$ \\
\hline $\begin{array}{l}10 . \\
165\end{array}$ & $\begin{array}{l}24 \\
\text { Apr } \\
1944\end{array}$ & $\begin{array}{l}\text { Antonio } \\
\text { Santin, } \\
\text { (Bishop of } \\
\text { Trieste) }\end{array}$ & Maglione & $\begin{array}{l}\text { Situation in Trieste } \\
\text { area: persecution of } \\
\text { Jews; shooting of } \\
\text { hostages; danger of } \\
\text { partisans; meeting } \\
\text { of bishop with } \\
\text { different groups. } \\
\text { Jews deported to } \\
\text { Auschwitz. }\end{array}$ \\
\hline $\begin{array}{l}10 . \\
204\end{array}$ & $\begin{array}{l}22 \\
\text { May } \\
1944\end{array}$ & $\begin{array}{l}\text { Giuseppe } \\
\text { Burzio, } \\
\text { Chargé } \\
\text { d'affairs, } \\
\text { Slovakia }\end{array}$ & Maglione & $\begin{array}{l}\text { Information on fate } \\
\text { of Jews deported to } \\
\text { Germany. Reference } \\
\text { made to Auschwitz } \\
\text { Protocol. Attached } \\
\text { document, not } \\
\text { published, may not } \\
\text { have been protocol } \\
\text { but a summary. }\end{array}$ \\
\hline $\begin{array}{l}10 . \\
263\end{array}$ & $\begin{array}{l}13 \mathrm{Jul} \\
1944\end{array}$ & $\begin{array}{l}\text { Casimir } \\
\text { Papée, } \\
\text { Polish } \\
\text { Ambass- } \\
\text { ador to } \\
\text { the Holy } \\
\text { See }\end{array}$ & Maglione & $\begin{array}{l}\text { News on deport- } \\
\text { ation of Hungarian } \\
\text { Jews. Estimated that } \\
400,000 \text { Jews sent to } \\
\text { Oswiecim (KL } \\
\text { Auschwitz- } \\
\text { Birkenau). }\end{array}$ \\
\hline $\begin{array}{l}10 . \\
279\end{array}$ & $\begin{array}{l}28 \mathrm{Jul} \\
1944\end{array}$ & $\begin{array}{l}\text { Filippo } \\
\text { Bernar- } \\
\text { dini, } \\
\text { Nuncio in } \\
\text { Switzer- } \\
\text { land }\end{array}$ & Maglione & $\begin{array}{l}\text { News of deport- } \\
\text { ation of Hungarian } \\
\text { Jews of Auschwitz, } \\
\text { and their extermin- } \\
\text { ation. Report based } \\
\text { on report of Rudolf }\end{array}$ \\
\hline
\end{tabular}




\begin{tabular}{|c|c|c|c|c|}
\hline & & & & $\begin{array}{l}\text { Vrba and Auschwitz } \\
\text { Protocols. }\end{array}$ \\
\hline $\begin{array}{l}10 . \\
330\end{array}$ & $\begin{array}{l}26 \\
\text { Sep } \\
1944\end{array}$ & $\begin{array}{l}\text { Domenico } \\
\text { Tardini, } \\
\text { Secretariat } \\
\text { of State }\end{array}$ & Orsenigo & $\begin{array}{l}\text { Plea to prevent } \\
\text { massacre of estimat- } \\
\text { ed } 45,000 \text { prisoners } \\
\text { at KL Auschwitz of } \\
\text { Polish, Italian and } \\
\text { other nationalities. }\end{array}$ \\
\hline $\begin{array}{l}10 . \\
333\end{array}$ & $\begin{array}{l}30 \\
\text { Sep } \\
1944\end{array}$ & $\begin{array}{l}\text { Amleto } \\
\text { Cicognani } \\
\text { Apostolic } \\
\text { Delegate } \\
\text { to USA }\end{array}$ & Sec State & $\begin{array}{l}\text { Request from dele- } \\
\text { gation of rabbis and } \\
\text { representative of } \\
\text { Jewish Committee } \\
\text { for prisoners in KL } \\
\text { Auschwitz. }\end{array}$ \\
\hline $\begin{array}{l}10 . \\
335\end{array}$ & $\begin{array}{l}02 \\
\text { Oct } \\
1944 \\
\end{array}$ & Sec State & $\begin{array}{l}\text { Italian } \\
\text { Embassy }\end{array}$ & $\begin{array}{l}\text { Steps taken for } \\
\text { prisoners in KL } \\
\text { Auschwitz. }\end{array}$ \\
\hline $\begin{array}{l}10 . \\
354\end{array}$ & $\begin{array}{l}13 \\
\text { Oct } \\
1944\end{array}$ & Orsenigo & Sec State & $\begin{array}{l}\text { Steps taken for } \\
\text { prisoners in KL } \\
\text { Auschwitz and } \\
\text { Pruszkow not } \\
\text { successful. Prusz- } \\
\text { kow used as a KL } \\
\text { for prisoners taken } \\
\text { during Warsaw } \\
\text { uprising. }\end{array}$ \\
\hline $\begin{array}{l}10 . \\
402\end{array}$ & $\begin{array}{l}21 \\
\text { Nov } \\
1944\end{array}$ & Tardini & $\begin{array}{l}\text { Giuseppe } \\
\text { Burzio, } \\
\text { Chargé } \\
\text { d'affaires, } \\
\text { Slovakia }\end{array}$ & $\begin{array}{l}\text { Request for new } \\
\text { effort for Slovak } \\
\text { Jews being sent to } \\
\text { Auschwitz. Asking } \\
\text { for an appeal for } \\
\text { Jews holding Amer- } \\
\text { ican citizenship. }\end{array}$ \\
\hline $\begin{array}{l}10 . \\
439\end{array}$ & $\begin{array}{l}25 \\
\text { Jan } \\
1945\end{array}$ & Tardini & Orsenigo & $\begin{array}{l}\text { Rumours that } \\
\text { retreating German } \\
\text { soldiers have }\end{array}$ \\
\hline
\end{tabular}




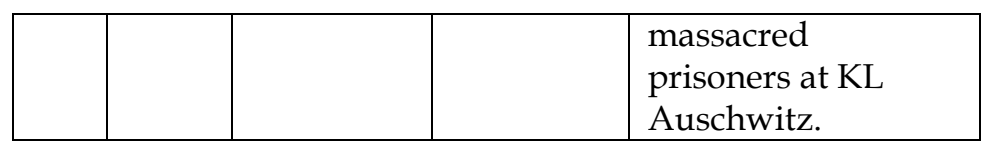

This selection of documents referring to Auschwitz is consistent with the emerging awareness of the extermination camp in other contemporary sources. Disbelief at reports of industrialised killing dominated Vatican and Allied responses until the spring of 1944 when the report of Auschwitz escapees, Rudolf Vrba and Alfred Wetzler, reached Switzerland. Its publication in London and New York led to a dramatic effort to pressure the Hungarian government to stop the trains to Auschwitz. The Vatican knew of the so-called 'Auschwitz Protocols' through the Swiss Nuncio, Filippo Bernardini in July 1944, but did not receive the document until October 1944.

\section{Conclusion}

ADSS represents one of the richest and most valuable sources for historians studying the role and roles of the Catholic Church during the years of the Holocaust. It does not contain everything, but then neither does any archive have 'everything'. What the student can and will find in ADSS is a substantial selection of documents that gives a comprehensive picture of how the Vatican and its representatives across Europe, and in this particular case, Slovakia, learned, in piecemeal fashion, of the ever-increasing dangers faced by the Jews, the responses and actions taken to ameliorate conditions and attempt the nigh-impossible, namely, stop the trains. The case of Slovakia shows one set of circumstances where the representatives of the Holy See did what they could with the information that was reported to them even when the results were meagre.

\section{References}

Actes et Documents du Saint-Siège relatifs à la Seconde Guerre mondiale, 12 vols, Vatican City (1965-1981). 
233

Friedländer, Saul (2007), Nazi Germany and the Jews 1939 -1945:

The years of extermination, New York, Harper Collins.

Paldiel, Mordecai (2006), Churches and the Holocaust: Unholy teaching, Good Samaritans and reconciliation, Jersey City NJ, KTAV.

Zuccotti, Susan (2000), Under His Very Windows: The Vatican and the Holocaust in Italy, New Haven, Yale University Press. 